\title{
PROBLEMS OF CLASSIFICATION AND CERTIFICATION BY CHEMICAL COMPOSITION OF SOME FUNGICIDES AND HERBICIDES
}

\author{
Marupova Manzura Aminovna ${ }^{1}$ \\ Former major of the customs service, \\ $\mathrm{PhD}$ of Fergana branch of the Tashkent Medical \\ Academy, \\ Uzbekistan $^{1}$
}

\author{
Ahadjonov Mavlonjon Mahmudjon o'g' $\mathbf{l i}^{2}$ \\ Assistant teacher of Fergana branch of the \\ Tashkent Medical Academy, \\ Uzbekistan $^{2}$
}

\author{
Kosimova Hafizakhon ${ }^{3}$ \\ Assistant teacher of Fergana Polytechnic Institute, \\ Uzbekistan $^{3}$
}

Article DOI: https://doi.org/10.36713/epra4424

\begin{abstract}
ANNOTATION
This article gives the types, meaning, application and classification of fungicides and herbicides. The role of the International Convention on the classification of goods, the significance of the State chemical Commission, as well as suggestions for improving their classification and certification of these substances in the commodity nomenclature of Foreign economic activity (HS code).

KEY WORDS: pesticide, herbicide, fungicide, plant pathogenic fungi, commodity nomenclature of foreign economic activity, position, subitem, sub-subitem, ingredient, indicator.
\end{abstract}

\section{INTRODUCTION}

More than 1.5 thousand different chemicals (herbicides, fungicides, insecticides, acaricides, defoliants, stimulants, regulators, etc.) allowed in agriculture are included in the book: "List of pesticides and agro chemicals allowed for use in agriculture of the Republic of Uzbekistan" in the 2017 edition of the State Commission on chemistry and plant protection under the Cabinet of Ministers (State chemical Commission). (And also play an important role in monitoring agricultural land in the alienation of protected areas). [1]

Most herbicides and fungicides from this list that are allowed for use for 5 years (they must alternate due to the adaptation of microorganisms to drugs) come from many countries of the world, including Germany, Japan, India, the United States, Russia, China, Denmark, and are also produced by LLC "Ifoda", "Inok Nur Baraka", "Samo farm service" and others. republic of Uzbekistan.
Since hundreds of new types of herbicides and fungicides are currently being produced, and when the global chemical industry supplies more than 250 types of herbicides and more than 300 types of fungicides to agricultural markets, it is necessary to systematize them for effective use in agriculture, develop modern methods of classification and certification for their chemical composition. [2]

The international Convention on the harmonized commodity description and coding system was adopted in order to promote international trade, simplify fees, reduce the cost of re-describing, classifying and coding goods when they move from one classification system to another in the process of international trade, promote the standardization of foreign trade documentation and the transmission of statistical data.

\section{OBJECTIVES}

Study of the chemical composition, physicochemical and Toxicological properties, as well as classification of herbicides and fungicides according 
to the HS code. Based on the research, proposals for improving the classification and accelerated methods of certification of these drugs as a product are planned.

\section{METHODOLOGY}

The research material is herbicides and fungicides that are used in the fight against weeds and phytopathogenic fungi. The research uses modern analytical methods to determine the chemical composition (active substance and other ingredients) of herbicides and fungicides.

In the commodity nomenclature of foreign Economic activity (HS code), adopted on June 14, 1983 in Brussels by the International Convention on the harmonized system of description and coding of goods for determining their marketability, they are classified in 38 groups and there are only a few subitems.

It becomes clear that over the next 50 years, new generations of herbicides and fungicides have appeared on the world agricultural market, which are exported and imported as goods, but there are no corresponding codes for them.

When classifying goods, other than certain properties (net weight, packaging), their other characteristics or trademarks, such as the amount and mechanism of the active substance in the product, the impact on the environment, and others are not used. For example, the most commonly used fungicides are assigned multiple places in group 38 based on position 3808. Despite the fact that fungicides have now been developed, containing dozens of new types of organic substances and hundreds of different additives.

In addition, we must take into account the risk of many problems when the chemical composition of the ingredients in the product is not fully understood and it is bad that the composition of the substances is not considered their brand secrets. This is confirmed by the fact that sometimes there are cases of poisoning of animals and people with food products where chemicals are used.

It cannot be said that the classification and certification of agricultural products in Uzbekistan meets the requirements of the international standard.
If you need to know the quality and quantity of the product, the information may be insufficient due to the lack of verification methods in both the State sanitary and epidemiological station and the State Department of standardization. After all, even in these local organizations, there are not enough modern accelerated methods for determining the quantitative and qualitative analysis of products, as well as devices for research.

It would be advisable to study the simplest, fastest and cheapest methods of chemical analysis of ingredient classification based on the chemical composition of ingredients used in agriculture and introduce ways to implement them in Uzbekistan.

At the same time, it is necessary to provide industry representatives with convenient and acceptable methods for classifying and standardizing products based on their chemical composition and, as far as possible, using harmless substitutes, which can serve as a basis for conducting scientific research.

One of the solutions to this problem may be scientific research and its results, conducted by the honored inventor of Uzbekistan, President of the Academy of folk medicine of Uzbekistan, doctor of chemical Sciences, Professor I. R. Askarov. He is the founder of the science of chemistry 02.00.09 "Chemistry of goods", which was born in Uzbekistan.

Herbicides by their effects on plants are divided into mass-acting (affecting all plant species in one field)and selective (only those groups that affect one plant and do not harm another). Herbicides of the first group are used in industrial facilities, airfields, Railways and highways, under high-voltage power lines, around drainage channels and in other places, while herbicides of the second group are used to protect cultivated plants from weeds [2].

They affect the cell membrane, meristem tissue, the process of cell mitosis, the light phase of photosynthesis (hill reaction). Some herbicides damage the cambium, and some slow down cell differentiation.

\section{STATISTICAL DESIGN}

The classification of fungicides and herbicides as products is shown in the following table. 
EPRA International Journal of Multidisciplinary Research (IJMR) - Peer Reviewed Journal Volume: 6 | Issue: 5 | May 2020 || Journal DOI: 10.36713/epra2013 || SJIF Impact Factor: 7.032 ||ISI Value: 1.188

Classification of fungicides and herbicides by HS code (version 2017)

\begin{tabular}{|c|c|}
\hline HS code & Name position \\
\hline 3808520000 & - - ISO (clophenotane), in packages with a net weight of no more than $300 \mathrm{~g}$ \\
\hline 3808590000 & - - other \\
\hline 3808610000 & $\begin{array}{l}\text { - goods mentioned in the note to subheadings } 2 \text { to this group: } \\
\text { - - in packages with a net weight of not more than } 300 \mathrm{~g}\end{array}$ \\
\hline 3808620000 & $\begin{array}{l}\text { - - in packages with a net weight of more than } 300 \mathrm{~g} \text {, but not more than } 7.5 \\
\mathrm{~kg}\end{array}$ \\
\hline 3808690000 & -- other \\
\hline 380891 & -- insecticides \\
\hline 380892 & - - fungicides: \\
\hline 3808921000 & - - - inorganic: \\
\hline 3808922000 & - - - preparations based on copper compounds \\
\hline 3808923000 & - - - other \\
\hline 3808924000 & - - - other: \\
\hline 3808925000 & - . - based on dithiocarbamates \\
\hline 3808926000 & - - - - based on benzimidazoles \\
\hline 3808929000 & - . - based on diazoles or triazoles \\
\hline 380893 & - - - - based on diazines or morpholines \\
\hline & - - - other \\
\hline 3808931100 & -- herbicides, anti-sprouting agents and plant growth regulators: \\
\hline 3808931300 & --- herbicides: \\
\hline 3808931500 & ---- based on phenoxyphytohormones \\
\hline 3808931700 & ---- based on triazines \\
\hline 3808932100 & ---- based on amides \\
\hline 3808932300 & ---- based on carbamates \\
\hline 3808932700 & ---- based on dinitroaniline compounds \\
\hline 3808933000 & ---- based on derivatives of urea, uracil or of sulphonilecarbomide \\
\hline 3808939000 & ---- other \\
\hline
\end{tabular}

Fungicides and herbicides are classified in 38 groups, having 3808 heading and respectively subpositions 380892 (fungicides) and 380893 (herbicides). [3]

According to the rules of the Convention (Belgium, 1983), the items and sub-items of goods do not change, and it is clear that the types of goods that belong to one sub-item have only a few places. Goods in most cases are classified based on net weight, but not chemical composition, for example, DDT (currently prohibited due to high toxicity) with a net

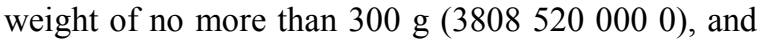
the rest, i.e. other 38085900000 .

\section{RESULTS}

Herbicides are classified according to active substances: based on phenoxyphythormones (3808 93 1100 ), based on triazines (3808 931300 ), based on amides (3808 93 150), based on carbamates (3808 93 170 ), based on dinitroaniline compounds (3808 93 210) and herbicides based on urea (urea), uracil or sulfonylcarbamide (3808 93230 0). However, they currently have many different chemical bases.

However, other targets (especially additives) were not used in the classification of herbicides when currently the active substances in herbicides are $5 \%$, $10 \%, 20 \%$ and $50 \%$, and respectively the remaining additives are $95 \%, 90 \%, 80 \%$ and $50 \%$.

\section{CONCLUSION}

In conclusion, given the above, we recommend you to consider the following parameters: their chemical composition (inorganic or organic), the number of active substances and additives in their composition, and their influence on Botanical classes of plants, the retention time in the soil, the effects, the time of leaching from soil, effect on soil microflora and animals, of course, the price in the global market.

The following should be noted:

- Classification (product code) should be the basis for certification in standardization;

- Export and import of goods by their classification and certification in accordance with the established procedure;

- Buy at cost and bring them to the international market by optimizing proper classification and certification based on cost;

- Especially on their basis to organize proper collection of payments;

- To protect the country economically; 
- Conservation of the environment, plants, animals, and human health.

\section{REFERENCES}

1. Abdullayev I.N., Marupov A.A., THE ANALYSIS OF LANDS IN SECURITY ZONES OF HIGH-VOLTAGE POWER LINES (POWER LINE) ON THE EXAMPLE OF THE FERGANA REGION, 6/2/2020, $p$ 55-58, ORCID: 0000-0002-5120-4359. https://doi.org/10.36713/epra3977

2. Khamraev A. H. and others Protection of grain and rice from pests, diseases and weeds. Uzbek-British joint venture Tashkent 1999.

3. Commodity nomenclature of foreign economic activity of the Republic of Uzbekistan (version 2017). Tashkent 2017. Ministry of foreign trade of the Republic of Uzbekistan, State customs Committee of the Republic of Uzbekistan, 2017.

4. " List of pesticides and agrochemicals permitted for use in agriculture of the Republic of Uzbekistan", developed by the State Commission on chemistry and plant protection (State chemical Commission). Application of the journal of plant protection and quarantine. 2016. 